\title{
Analisis Postur Kerja Karyawan Dibagian Pengangkatan Bahan Baku Dengan Menggunakan Metode Owas (Ovako Working Posture Analysis) Dan Rula (Rapid Upper Limb Asessement) Di PT.Sumatera Tropical Spices.
}

Robino Indan, Nila Kusuma Pratiwi, Mufrida Meri.Z

Universitas Putra Indonesia "YPTK” Padang

*Email : mufridameri@upiyptk.ac.id

\begin{abstract}
Abstrak
Penggunaan tenaga manusia sebagai pekerja sangatlah dominan terutama kegiatan penanganan material secara manual (Manual Material Handling). PT.SUMATERA TROPICAL SPICES mengolah rempahrempah menjadi bumbu masak dan penyedap masakan yaitu kulit kayu manis, untuk bagian pembongkaran bahan baku mentah mereka masih menggunakan tenaga manusia sebagai alat pemindahan barang dari truk pengangkut bahan baku menuju gudang yang mana sangat memungkin terjadinya Musculoskeletal Disorders, Untuk mengetahui tingkat resiko cedera pada pekerja dan keluhan nya maka di analisis dengan menggunakan metode OWAS (Ovako Working Posture Analysis) dan metode RULA (Rapid Upper Limb Asessement).Data penelitian di dapatkan menggunakan kuesioner dengan jumlah responden sebanyak 13 orang dan foto pekerja yang sedang mengangkat dan menurunkan bahan baku. Untuk kategori resiko OWAS terdapat 5 posisi yang sangat tinggi Sedangkan untuk kategori resiko RULA yang bernilai 3 dan 4 menghasilkan tingkat kategori resiko sedang dan tindakan yang harus.
\end{abstract}

Kata kunci : Manual Material Handling, Owas dan Rula, Resiko

\section{PENDAHULUAN}

\subsection{Latar Belakang}

Penggunaan tenaga manusia sebagai pekerja sangatlah dominan terutama kegiatan penanganan material secara manual (Manual Material Handling). Kelebihan nya bila dibandingkan dengan penangan material menggunakan alat bantu adalah fleksibilitas gerakan yang dapat dilakukan untuk beban-beban ringan. Akan tetapi aktivitas Manual Material Handling teridentifikasi beresiko tinggi sebagai penyebab utama timbulnya cedera pada otot rangka (Musculoskeletal Disorders). Musculoskeletal Disorders pada umumnya terjadi karena kontraksi otot yang berlebihan akibat beban kerja yang berat dengan durasi pembebanan yang panjang.

PT.SUMATERA TROPICAL SPICES merupakan sebuah perusahaan yang mengolah rempah-rempah menjadi bumbu masak dan penyedap masakan yaitu kayu manis. Perusahaan ini menjual hasil olahan kayu manisnya tidak hanya di domestik tapi juga mancanegara. Sedangkan kayu manis tersebut didatangkan dari petani-petani kayu manis yang ada di daerah kabupaten Padang Pariaman.

Penulis mengamati di stasiun kerja pembongkoran bahan baku mentah kulit kayu manis yang memiliki berat $60 \mathrm{~kg} / \mathrm{karung}$ yang mana pada saat operator melakukan pengangkatan bahan baku dari truk menuju gudang proses tersebut menyebabkan terjadinya musculoskeletal disorders, maka dari itu peneliti menganalisis tingkat resiko cidera yang terjadi dari dampak muskuloskeletal disorder.

\subsection{Rumusan Masalah}

1. Bagaimana cara mendapatkan nilai OWAS dan RULA?

2. Jenis keluhan apa saja yang menyebabkan Musculoskeletal Disorders? 


\section{Bagaimana cara mengatasi MSDs di PT. PT.SUMATERA TROPICAL SPICES?}

\subsection{Batasan Masalah}

1. Penelitian ini menggunakan kuesioner Nordic Bodi Map kepada pekerja.

2. Penelitian ini menggunakan metode OWAS dan RULA.

3. Penelitian ini dilakukan dengan operator pengangkutan bahan baku sebanyak 13 orang pada proses pengangkutan bahan baku ke gudang bahan baku.

4. Penelitian dilakukan pada bagian penyimpanan bahan baku pembelian dari petani yang disimpan di gudang.

\subsection{Tujuan Penelitian}

Adapun tujuan dalam penelitian ini :

1. Untuk mengetahui adanya keluhan muskuloskeletal disorder pada pekerja pengangkatan bahan baku.

2. Untuk mengetahui keluhan-keluhan muskuloskeletal disorder dengan menggunakan kuesioner Nodic Body Map.

3. Untuk mengetahui tingkat resiko cedera pada pekerja dengan menggunakan metode OWAS dan RULA.

\section{LANDASAN TEORI}

\subsection{Penilaian Risiko Keluhan Sistem Muskuloskeletal}

Kecelakaan kerja adalah suatu kejadian yang jelas tidak dikehendaki dan sering kali tidak terduga semula yang dapat menimbulkan kerugian baik waktu, harta benda/property maupun korban jiwa yang terjadi di dalam suatu proses kerja industri atau yang berkaitan dengannya (Tarwaka, 2008).

Disebut tidak terduga karena dibelakang peristiwa kecelakaan tidak terdapat unsur kesengajaan dan perencanaan. Kejadian ini juga dikatakan tidak diinginkan atau diharapkan, karena setiap peristiwa kecelakaan akan selalu disertai kerugian baik fisik maupun mental. Serta selalu menimbulkan kerugian dan kerusakan, yang sekurang-kurangnya menyebabkan gangguan proses kerja (Tarwaka, 2008). Keluhan pada sistem muskuloskeletal adalah keluhan pada bagian-bagian otot rangka yang dirasakan oleh seseorang mulai dari keluhan sangat ringan sampai sangat sakit. Apabila otot menerima beban statis secara berulang dan dalam waktu yang lama, akan dapat menyebabkan keluhan berupa kerusakan pada sendi, ligamen dan tendon (Tarwaka, 2015).

Secara garis besar keluhan otot dapat dikelompokan menjadi dua yaitu (Tarwaka, 2015)

1. Keluhan sementara (reversible), yaitu keluhan otot yang tterjadi pada saat otot menerima beban statis, namun demikian keluhan tersebut akan segera hilang apabila pemberian beban dihentikan.

2. Keluhan Menetap (persistent), yaitu keluhan otot yang bersifat menetap. Walaupun pemberian beban kerja telah dihentikan, namun rasa sakit pada otot masih terus berlanjut.

Keluhan sistem muskuloskeletal pada umumnya terjadi karena kontraksi yang berlebihan akibat pemberian beban kerja yang terlalu berat dengan durasi pembebanan yang panjang. Sebaliknya, keluhan otot kemungkinan tidak terjadi apabila kontraksi otot hanya berkisar antara 15-20\% dari kekuatan otot maksimum. Namun apabila kontraksi oto melebihi 20\% maka peredaran darah ke otot berkurang menurut tingkat kontraksi yang dipengaruhi oleh besarnya tenaga yang diperlukan (Tarwaka, 2015). 


\subsection{Metode Postur Kerja Ovako Work Posture Analysis System (OWAS)}

Metode ini pertama kali diperkenalkan oleh seorang penulis dari Osmo Karhu Finlandia, tahun 1977 dengan judul "Correcting Working Postures Im Industry: A practical method for analysis" yang diterbitkan dalam jurnal "Applied Ergonomics"(Tarwaka, 2015). OWAS merupakan metode analisis sikap kerja yang mendefinisikan pergerakan bagian tubuh punggung, lengan, kaki, dan beban berat yang diangkat. Masing-masing anggota tubuh tersebut diklasifikasikan menjadi sikap kerja.

Aplikasi metode OWAS didasarkan pada hasil pengamatan dari berbagai posisi yang diambil pada pekerja selama melakukan pekerjaannya dan digunakan untuk mengidentifikasi dengan posisi yang berbeda sebagai hasil dari kemungkinan kombinasi postur tubuh bagian belakang (4 posisi), lengan (3 posisi), kaki (7 posisi), dan pembebanan (3 interval) (Tarwaka, 2015).

Berikut ini adalah klasifikasi sikap bagian tubuh yang diamati untuk dianalisa dan dievaluasi (Tarwaka, 2015):

1. Posisi Punggung : Digit pertama "kode posisi"

Untuk mengatur nilai digit yang mempresentasikan punggung harus ditentukan apakah posisi yang terjadi pada garis punggung adalah lurus, membungkuk, memuntir.

a. Punggung lurus

Garis sumbu badan pekerja sejajar dengan garis sumbu kaki dan pinggul dengan "kode posisi" 1.

b. Punngung membungkuk

Badan posisi fleksibel dengan sudut fleksi tetapi dapat dipertimbangkan untuk inklinasi $>20^{\circ}$ "kode posisi" 2.

c. Punggung memuntir

Badan memuntir atau inklinasi lateral sebesar $>20^{\circ}$ "kode posisi" 3 .

d. Punggung ditekuk memuntir

Badan dengan posisi fleksi dan rotasi atau miring secara simulta. "kode posisi" 4.
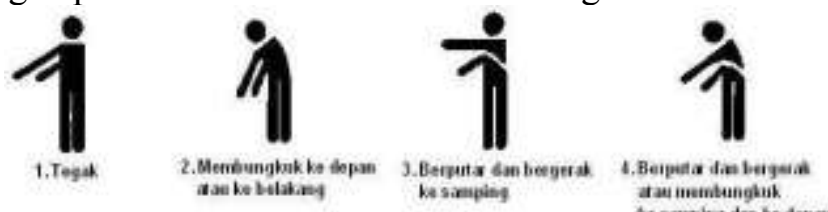

Gambar 2.1 Klasifikasi sikap kerja bagian punggung

(Sumber : Wresni, 2012)

2. Posisi Lengan : Digit kedua "kode posisi"

Berikut penjelasan posisi lengan antara lain yaitu :

a. Kedua lengan berada dibawah bahu "kode posisi" 1

b. Satu lengan berada dibawah dan satunya diatas, lengan pekerja pada saat bekerja yang satu dibawah dan yang satu lagi diatas ketinggian bahu. "kode posisi" 2.

c. Kedua lengan diatas bahu "kode posisi" 3 .

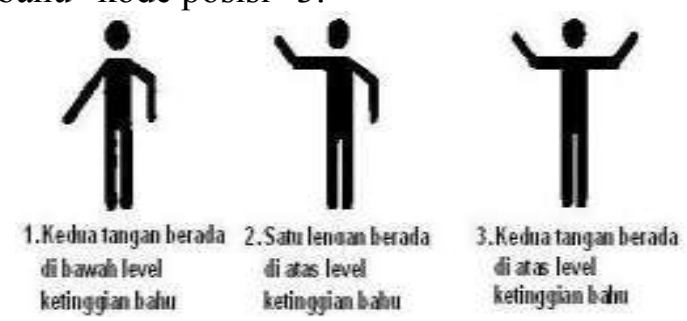

Gambar 2.2 Klasifikasi sikap kerja bagian lengan

(Sumber: Wresni, 2012)

3. Posisi kaki: Digit ketiga "kode posisi"

Posisi kaki harus dianalisa dalam tiga digit pertama dari kode tampilan yang mengidentifikasikan bagian-bagian tubuh yang dianalisa dengan metode ini. 
a. Posisi duduk

Pekerja melakukan pekerjaan dengan posisi duduk "kode posisi" 1.

b. Berdiri

Dengan kedua kaki lurus dengan berat badan seimbang antara kedua kaki "kode posisi" 2.

c. Berdiri

Lainnya dengan menekuk dengan berat badan dengan satu kaki lurus dan kaki seimbang antara kedua kaki "kode posisi" 3.

d. Berdiri atau jongkok

Dengan kedua kaki agak ditekuk dan berat seimbang antara kedua kaki dengan sudut paha betis atau $>150^{\circ}$ sudut yang lebih besar dapat dipertimbangkan bahwa kaki lurus "kode posisi" 4.

e. Berdiri atau jongkok

Dengan kedua kaki ditekuk dan keseimbnagan berat badan antara kedua kaki. Dianggap bahwa terjadi sudut paha betis atau $>150^{\circ}$ sudut yang lebih besar akan dianggap kaki lurus "kode posisi" 5.

f. Kaki dengan posisi berlutut Pekerjaan menopangkan salah satu atau kedua lutut dilantai "kode posisi" 6 .

g. Berjalan

Pekerja dalam posisi berjalan pada saat melakukan pekerjaan "kode posisi" 7

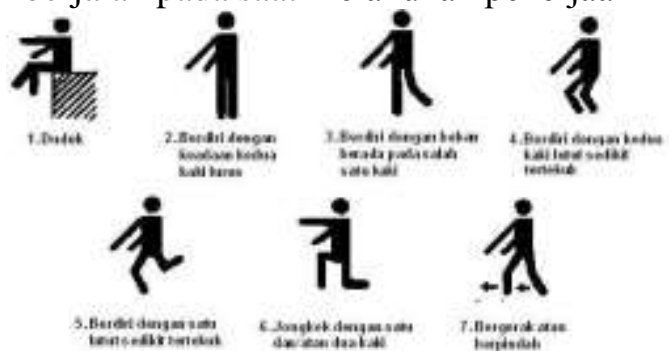

Gambar 2.3 Klasifikasi sikap kerja bagian kaki (Sumber : Wresni, 2012)

4. Beban dan Kekuatan (force) di topang : Digit keempat "kode posisi"

Pada tahap ini harus ditentukan kisaran beban dimana metode in mengusulkan tiga kisaran beban.

a. Berat beban adalah kurang dari $10 \mathrm{Kg}(\mathrm{W}=10 \mathrm{Kg})$ 'kode posisi 1 .

b. Berat beban adalah $10 \mathrm{Kg}-20 \mathrm{Kg}(10 \mathrm{Kg}<\mathrm{W}=20 \mathrm{Kg})$ 'kode posis" 2 .

c. Berat beban adalah lebih besar dari $20 \mathrm{Kg}(\mathrm{W}>20 \mathrm{Kg})$ 'kode posis" 3.

\subsection{Metode Postur Kerja Rapid Upper Limb Assessment (RULA)}

RULA (Rapid Upper Limb Assessment) dikembangkan oleh Dr. Lynn McAtamney dan Dr. Nigel Corlett yang merupakan ergonom dari universitas di Nottingham (University of Nottingham's Institute of Occupational Ergonomis). Metode RULA merupakan suatu metode dengan menggunakan target postur tubuh untuk mengestimasi tejadinya risiko gangguan sistem muskuloskeletal khususnya pada bagian tubuh bagian atas (upper limb disorders)

Seperti adanya gerakan repetitif, pekerjaan diperlukan pengarahan kekuatan, aktivitas pada otot statis pada sistem muskuloskeletal,dll (Tarwaka, 2015).

Metode RULA merupakan alat untuk melakukan analisa awal yang mampu menentukan seberapa jauh risiko pekerja yang terpengaruh oleh faktor-faktor penyebab cedera yaitu (Tarwaka, 2015):

1. Postur tubuh

2. Kontraksi otot statis

3. Gerakan repetitif

4. Pengerahan tenaga dan pembebanan

Keterbatasan lain pada metode ini adalah bahwa penilaian postur pekerja jugaa tidak meliputi analisa posisi posisi ibu jari atau jari-jari tangan lainnya meski pengerahan kekuatan yang 
dikeluarkan jari-jari tersebut dihitung. Tidak dilakukan pengukuran waktu meskipun faktor waktu menjadi penting karena berhubungan dengan kelelahan otot dan kerusakan jaringan akibat kontraksi otot (Tarwaka, 2015).

Berikut merupakan penjelasan prosedur aplikasi metode RULA antara lain sebagai berikut (Tarwaka, 2015):

1. Menentukan siklus kerja dan mengobservasi pekerja selama variasi siklus kerja tersebut.

2. Memilih postur tubuh yang akan dinilai.

3. Memutuskan untuk menilai kedua sisi anggota tubuh.

4. Menghitung grand skor dan action level untuk menilai kemungkinan risiko yang terjadi.

5. Menghitung grand scor dan action level untuk untuk menilai kemungkinan risiko yang terjadi.

6. Merevisi skor postur tubuh untuk anggota tubuh yang berbedayang digunakan untuk menentukan dimana perbaikan diperlukan.

7. Redesain stasiun kerja mengadakan perubahan untuk perbaikan postur tubuh saat kerja diperlukan.

8. Jika perubahan perbaiakan telah dilakukan, perlu melakukan penilaian kembali terhadap postur tubuh dengan menggunakan metode RULA untuk memastikan bahwa perbaikan telah berjalan sesuai dengan yang diingnkan (Tarwaka, 2015).

\section{METODOLOGI PENELITIAN}

Metode penelitian ini menjelaskan mengenai langkah-langkah yang dilakukan dalam menyelesaikan permasalahan yang peneliti angkat pada PT.Sumatera Tropical Spices. Diagram alir dari metode penelitian yang digunakan dalam penelitian ini dapat digambarkan sebagai berikut:

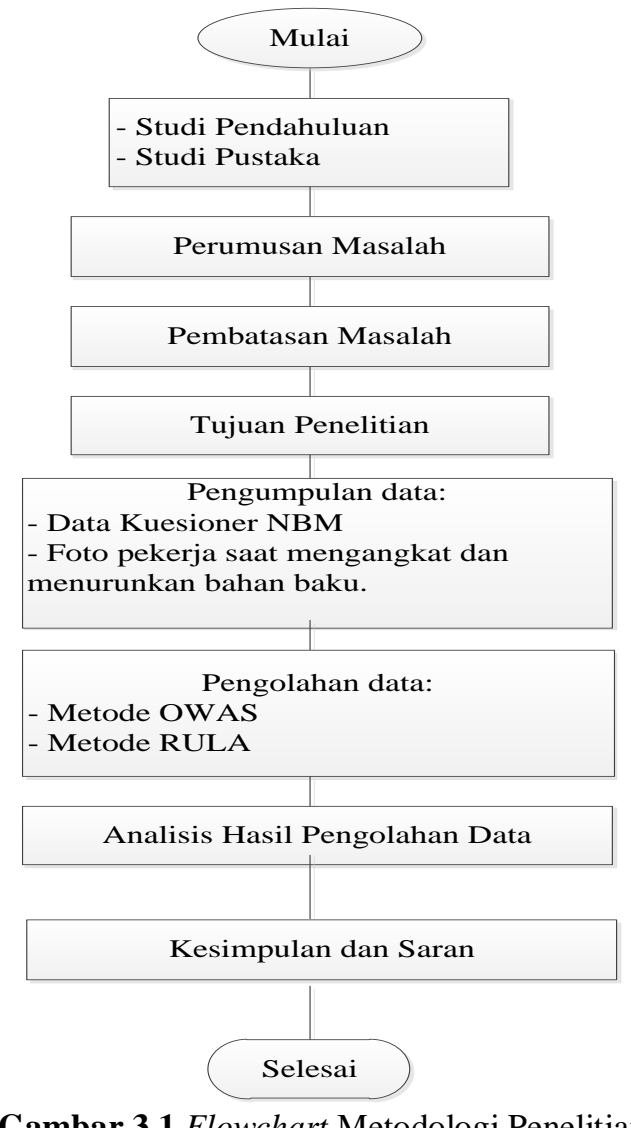

\section{HASIL DAN PEMBAHASAN}


Pengolahan data menggunakan metode OWAS dan RULA untuk menentukan seberapa besar muskuloskeletal disorders operator di PT.STS hal itu dapat diukur dengan memberi sudut pada gambar operator.

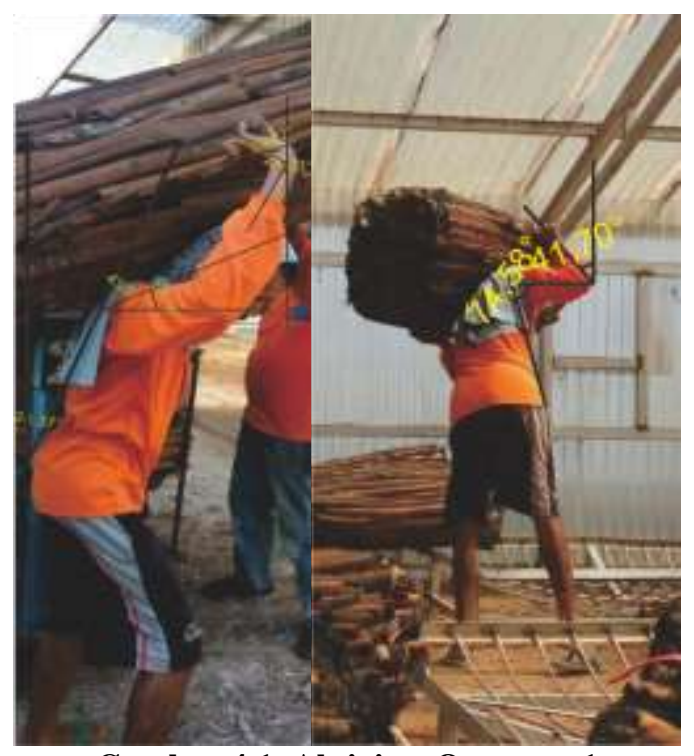

Gambar 4.1. Aktivitas Operator 1

(Sumber: PT.STS, 2018)

Pada saat melakukan pengangkatan, posisi punggung operator membungkuk beberapa derajat sehingga mempunyai skor 2 , posisi kedua kaki operator berdiri dengan kedua lutut agak menekuk $<150^{\circ}$ sehingga mempunyai skor 4 , posisi lengan kedua lengannya berada di atas ketinggian bahu sehingga mempunyai skor 3 , sedangkan beban sudah ditentukan perusahaan yaitu $60 \mathrm{~kg}$ sehingga mempunyai skor 3 .

Pada saat melakukan penurunan, posisi punggung operator membungkuk dan melakukan gerakan memuntir sehingga mempunyai skor 4 , posisi kedua kaki operator berdiri dengan kedua lutut agak menekuk $<150^{\circ}$ sehingga mempunyai skor 4 , posisi kedua lengan operator salah satu lengan berada diatas ketinggian bahu sehingga mempunyai skor 2 , sedangkan beban mempunyai skor 3

Untuk skor RULA terbagi atas beberapa grup pada saat melakukan pengangkatan, grup A untuk lengan atas mempunyai skor 2, lengan bawah mempunyai skor 2, pergelangan tangan mempunyai skor 3 sedangkan untuk grup B meliputi bagian leher dengan skor 3, badan mempunyai skor 3, kaki mempunyai skor 1 .

Untuk skor RULA terbagi atas beberapa grup pada saat melakukan penurunan, grup A untuk lengan atas mempunyai skor 2, lengan bawah mempunyai skor 2, pergelangan tangan mempunyai skor 1 sedangkan untuk grup B meliputi bagian leher dengan skor 3, badan mempunyai skor 3, kaki mempunyai skor 1. Dari penilaian diatas dapat dimasukkan kedalam tabel-tabel penilaian untuk skor OWAS dan RULA.

Tabel 4.1 Pengklasifikasian Kategori Resiko "Kode Posisi” Pada Kombinasi Posisi Pengangkatan 


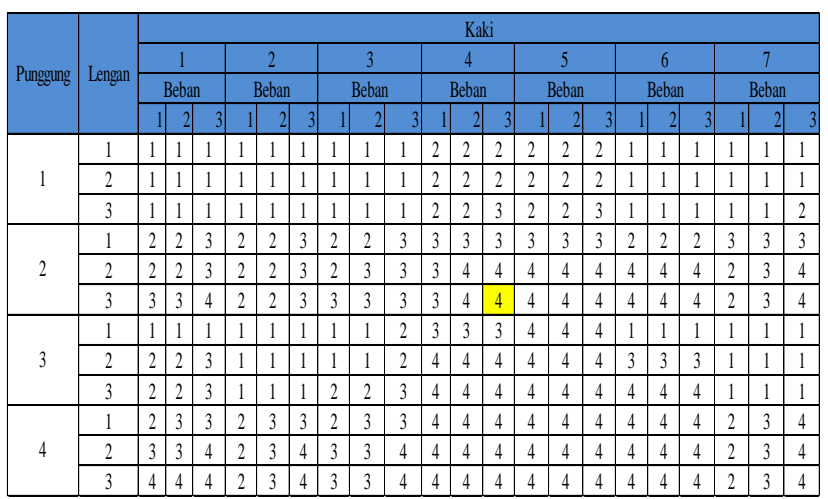

(Sumber : Tarwaka, 2015)

Tabel 4.2 Pengklasifikasian Kategori Resiko “Kode Posisi” Pada Kombinasi Posisi Penurunan

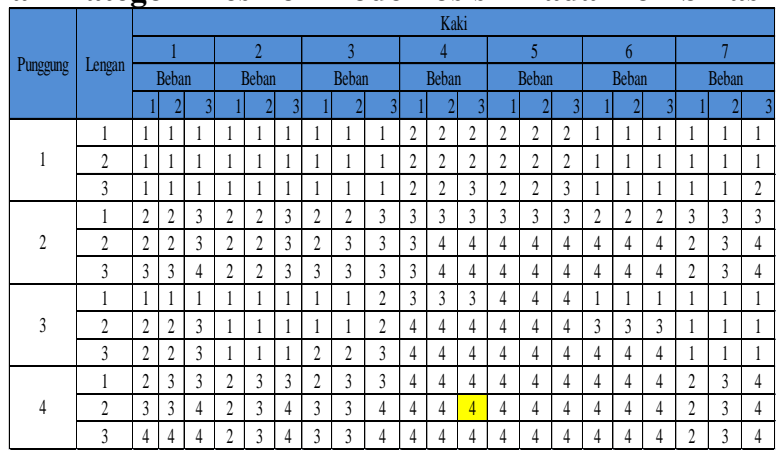

(Sumber : Tarwaka, 2015)

Tabel 4.3 Skor Postur Grup A Pada Proses Pengangkatan

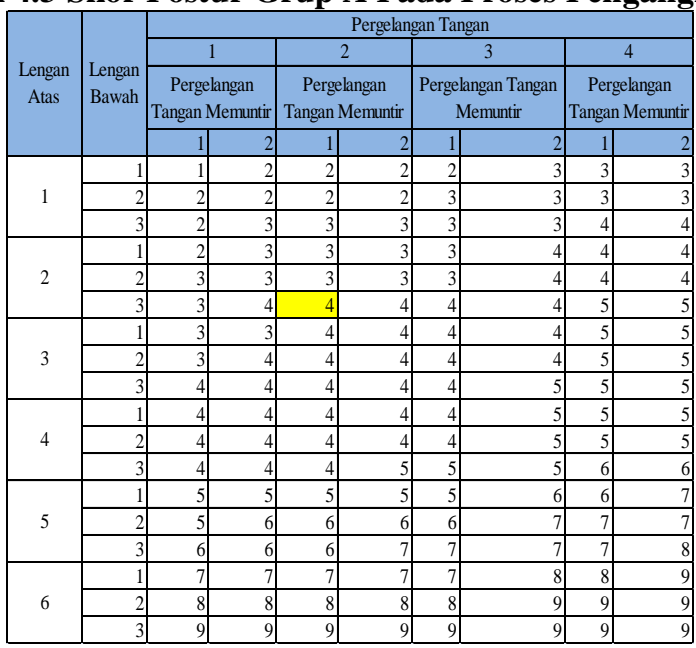

(Sumber : Tarwaka, 2015)

Tabel 4.5 Skor Postur Grup A Pada Proses Penurunan 


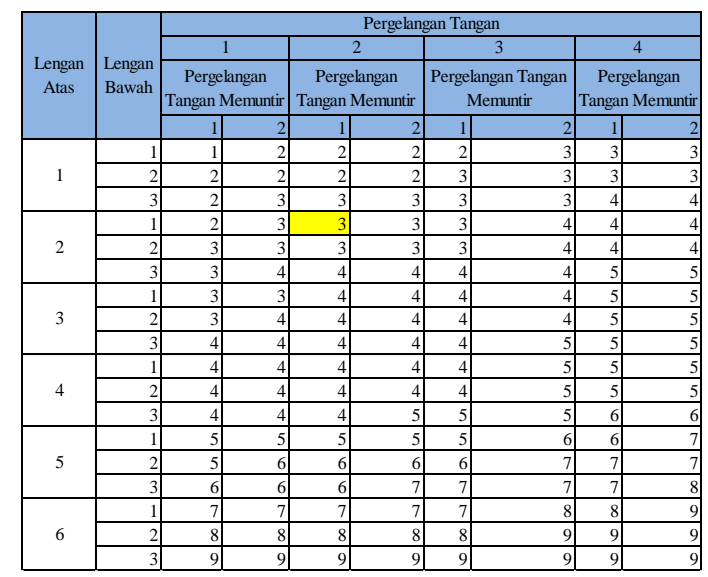

(Sumber : Tarwaka, 2015)

Tabel 4.6 Skor Postur Grup B Pada Proses Pengangkatan

\begin{tabular}{|c|c|c|c|c|c|c|c|c|c|c|c|c|}
\hline \multirow{4}{*}{ Leher } & \multicolumn{12}{|c|}{ Badan } \\
\hline & \multirow{2}{*}{\multicolumn{2}{|c|}{ Kaki }} & 2 & & 3 & & 4 & & 5 & & 6 & \\
\hline & & & \multicolumn{2}{|c|}{ Kaki } & \multicolumn{2}{|c|}{ Kaki } & \multicolumn{2}{|c|}{ Kaki } & \multicolumn{2}{|c|}{ Kaki } & \multicolumn{2}{|c|}{ Kaki } \\
\hline & 1 & 2 & 1 & 2 & 1 & 2 & 1 & 2 & 1 & 2 & 1 & 2 \\
\hline 1 & 1 & 3 & 2 & 3 & 3 & 4 & 5 & 5 & 6 & 6 & 7 & 7 \\
\hline 2 & 2 & 3 & 2 & 3 & 4 & 5 & 5 & 5 & 6 & 7 & 7 & 7 \\
\hline 3 & 3 & 3 & 3 & 4 & 4 & 5 & 5 & 6 & 6 & 7 & 7 & 7 \\
\hline 4 & 5 & 5 & 5 & 6 & 6 & 7 & 7 & 7 & 7 & 7 & 8 & 8 \\
\hline 5 & 7 & 7 & 7 & 7 & 7 & 8 & 8 & 8 & 8 & 8 & 8 & 8 \\
\hline 6 & 8 & 8 & 8 & 8 & 8 & 8 & 8 & 9 & 9 & 9 & 9 & 9 \\
\hline
\end{tabular}

Tabel 4.7 Skor Postur Grup B Pada Proses Penurunan

\begin{tabular}{|c|c|c|c|c|c|c|c|c|c|c|c|c|}
\hline \multirow{4}{*}{ Leher } & \multicolumn{12}{|c|}{ Badan } \\
\hline & \multicolumn{2}{|c|}{1} & \multicolumn{2}{|c|}{2} & \multicolumn{2}{|c|}{3} & \multicolumn{2}{|c|}{4} & \multicolumn{2}{|l|}{5} & \multicolumn{2}{|c|}{6} \\
\hline & \multicolumn{2}{|c|}{ Kaki } & \multicolumn{2}{|c|}{ Kaki } & \multicolumn{2}{|c|}{ Kaki } & \multicolumn{2}{|c|}{ Kaki } & \multicolumn{2}{|c|}{ Kaki } & \multicolumn{2}{|c|}{ Kaki } \\
\hline & 1 & 2 & 1 & 2 & 1 & 2 & 1 & 2 & & 2 & 1 & 2 \\
\hline 1 & 1 & 3 & 2 & 3 & 3 & 4 & 5 & 5 & 6 & 6 & 7 & \\
\hline 2 & 2 & 3 & 2 & 3 & 4 & 5 & 5 & 5 & 6 & 7 & 7 & \\
\hline 3 & 3 & 3 & 3 & 4 & 4 & 5 & 5 & 6 & 6 & 7 & 7 & \\
\hline 4 & 5 & 5 & 5 & 6 & 6 & 7 & 7 & 7 & 7 & 7 & 8 & \\
\hline 5 & 7 & 7 & 7 & 7 & 7 & 8 & 8 & 8 & 8 & 8 & 8 & \\
\hline 6 & 8 & 8 & 8 & 8 & 8 & 8 & 8 & 9 & 9 & 9 & 9 & \\
\hline
\end{tabular}

Tabel 4.8 Grand Skor RULA Pengangkatan

\begin{tabular}{|c|c|c|c|c|c|c|c|}
\cline { 2 - 9 } \multicolumn{1}{c|}{} & \multicolumn{7}{c|}{ Skor D } \\
\hline Skor C & 1 & 2 & 3 & 4 & 5 & 6 & $7+$ \\
\hline 1 & 1 & 2 & 3 & 3 & 4 & 5 & 5 \\
\hline 2 & 2 & 2 & 3 & 4 & 4 & 5 & 5 \\
\hline 3 & 3 & 3 & 3 & 4 & 4 & 5 & 6 \\
\hline 4 & 3 & 3 & 3 & 4 & 5 & 6 & 6 \\
\hline 5 & 4 & 4 & 4 & 5 & 6 & 7 & 7 \\
\hline 6 & 4 & 4 & 5 & 6 & 6 & 7 & 7 \\
\hline 7 & 5 & 5 & 6 & 6 & 7 & 7 & 7 \\
\hline 8 & 5 & 5 & 6 & 7 & 7 & 7 & 7 \\
\hline \multicolumn{7}{|c|}{ Sumber: Tarwaka, 2015) } \\
\end{tabular}

Tabel 4.9 Grand Skor RULA Penurunan 


\begin{tabular}{|c|c|c|c|c|c|c|c|}
\cline { 2 - 9 } \multicolumn{1}{c|}{} & \multicolumn{7}{c|}{ Skor D } \\
\hline Skor C & 1 & 2 & 3 & 4 & 5 & 6 & $7+$ \\
\hline 1 & 1 & 2 & 3 & 3 & 4 & 5 & 5 \\
\hline 2 & 2 & 2 & 3 & 4 & 4 & 5 & 5 \\
\hline 3 & 3 & 3 & 3 & 4 & 4 & 5 & 6 \\
\hline 4 & 3 & 3 & 3 & 4 & 5 & 6 & 6 \\
\hline 5 & 4 & 4 & 4 & 5 & 6 & 7 & 7 \\
\hline 6 & 4 & 4 & 5 & 6 & 6 & 7 & 7 \\
\hline 7 & 5 & 5 & 6 & 6 & 7 & 7 & 7 \\
\hline 8 & 5 & 5 & 6 & 7 & 7 & 7 & 7 \\
\hline \multicolumn{7}{|c|}{ Sumber : Tarwaka, 2015) } \\
\hline
\end{tabular}

\section{KESIMPULAN}

Berdasarkan data yang telah diolah dan di analisis maka, di dapatkan kesimpulan sebagai berikut :

1. Untuk kategori resiko OWAS terdapat 5 posisi yang sangat tinggi sehingga tindakan yang harus dilakukan adalah adanya tindakan yang harus mengubah posisi operator tersebut dalam melakukan pengangkatan secepatnya, kemudian 15 posisi yang tinggi sehingga tindakan yang harus dilakukan adalah pengubahan posisi operator dalam melakukan pekerjaan. Sedangkan

2. untuk kategori resiko RULA yang bernilai 3 dan 4 menghasilkan tingkat kategori resiko sedang dan tindakan yang harus dilakukan adalah menginvestigasi penyebab yang menimbulkan kategori bernilai sedang dan adanya perubahan sikap dalam bekerja.

\section{DAFTAR PUSTAKA}

Anggraini,Wresni dan Pratama Mulya A.2012. Analisis Postur Kerja Dengan Menggunakan Metode Ovako Working Analysis System (Owas) Pada Stasiun Pengepakan Bandela Di PT. Riau Crumb Rubber Factory Pekanbaru. Jurnal: Sains, Teknologi dan Industri Vol. 10. No. 1.

Anita, Julia dan Aziz, Nasir dan Yunus, Mukhlis.3013. Pengaruh Penempatan Dan Beban Kerja Terhadap Motivasi Kerja Dan Dampaknya Pada Prestasi Kerja Pegawai Dinas Tenaga Kerja Dan Mobilitas Penduduk Aceh.Jurnal: Manajemen Vol. 2, No. 1, November 2013: 70.

Chandra,Riny dan Adriansyahi,Dodi.2017:Pengaruh Beban Kerja dan Stres Kerja terhadap Kinerja Karyawan pada PT. Mega Auto Central Finance Cabang di Langsa. Jurnal: Manajemen Dan Keuangan, Vol.6, No.1, Mei 2017: 671-672.

Iridiasti,Hardianto,Dkk.2014.Ergonomi Suatu Pengantar.Bandung:PT. Remaja Rosdakarya. Nurmianto,Eko.2003.Ergonomi Konsep Dasar dan Aplikasinya.Surabaya:Guna Widya. Sutalaksana,Iftikar Z,Dkk.2006. Teknik Perancangan Sistem Kerja.Bandung: Intitut Teknologi Bandung.

Tarwaka.2015.Ergonomi Industri Dasar-Dasar Pengetahuan Ergonomi Dan Aplikasi Ditempat Kerja. Surakarta: Harapan Press.

Yasa.2013. Manajemen Risiko Pada Bandara Soekarno Hatta Berbasis Iso 31000.Jurnal:Teknik Industri Vol. 14, No. 2, Agustus 2013: 116-129 